\title{
Parathyroid Cell Proliferation in Normal and Chronic Renal Failure Rats The Effects of Calcium, Phosphate, and Vitamin D
}

Tally Naveh-Many, Ruth Rahamimov, Nelly Livni, and Justin Silver

Minerva Center for Calcium and Bone Metabolism, Nephrology Services, Hadassah University Hospital, Jerusalem il-91120, Israel

\begin{abstract}
Secondary hyperparathyroidism is characterized by an increase in parathyroid (PT) cell number, and parathyroid hormone (PTH) synthesis and secretion. It is still unknown as to what stimuli regulate PT cell proliferation and how they do this. We have studied rats with dietary-induced secondary hyper- and hypoparathyroidism, rats given 1,25dihydroxyvitamin $D_{3}\left(1,25(O H)_{2} D_{3}\right)$ and rats after 5/6 nephrectomy for the presence of PT cell proliferation and apoptosis. PT cell proliferation has been measured by staining for proliferating cell nuclear antigen (PCNA) and apoptosis by in situ detection of nuclear DNA fragmentation and correlated with serum biochemistry and PTH mRNA levels. A low calcium diet led to increased levels of PTH mRNA and a 10-fold increase in PT cell proliferation. A low phosphate diet led to decreased levels of PTH mRNA and the complete absence of PT cell proliferation. $1,25(\mathrm{OH})_{2} \mathrm{D}_{3}(25 \mathrm{pmol} / \mathrm{d} \times 3)$ led to a decrease in PTH mRNA levels and unlike the hypophosphatemic rats there was no decrease in cell proliferation. There were no cells undergoing apoptosis in any of the experimental conditions. The secondary hyperparathyroidism of 5/6 nephrectomized rats was characterized by an increase in PTH mRNA levels and PT cell proliferation which were both markedly decreased by a low phosphate diet. The number of PCNA positive cells was increased by a high phosphate diet. Therefore hypocalcemia, hyperphosphatemia and uremia lead to PT cell proliferation, and hypophosphatemia completely abolishes this effect. Injected $1,25(\mathrm{OH})_{2} D_{3}$ had no effect. These findings emphasize the importance of a normal phosphate and calcium in the prevention of PT cell hyperplasia. (J. Clin. Invest. 1995. 96:1786-1793.) Key words: parathyroid hormone - apoptosis - hyperplasia $-1,25(\mathrm{OH})_{2} \mathrm{D}_{3} \cdot$ chronic renal failure.
\end{abstract}

\section{Introduction}

In the normal parathyroid gland very few cells proliferate (1). In secondary hyperparathyroidism there is an increase in para-

\footnotetext{
Address correspondence to Justin Silver M.D., Nephrology Services, Hadassah Hospital, PO Box 12000, Jerusalem, Israel 91120. Phone: 2 436778; FAX: 2 421234; E-mail: silver @gene.md.huji.ac.il

Received for publication 1 May 1995 and accepted in revised form 7 July 1995.
}

J. Clin. Invest.

(C) The American Society for Clinical Investigation, Inc.

0021-9738/95/10/1786/08 \$2.00

Volume 96, October 1995, 1786-1793 thyroid (PT) ${ }^{1}$ cell number, in addition to the major increase in the function of each cell to express more parathyroid hormone (PTH) mRNA and secrete more PTH. The stimuli which lead to increased PTH gene expression, translation and secretion are well characterized. In vivo, these include low calcium, high phosphate and estrogens (2-4). The factors which lead to decreased PTH gene expression in vivo are 1,25-dihydroxyvitamin $\mathrm{D}_{3}\left(1,25(\mathrm{OH})_{2} \mathrm{D}_{3}\right)(5)$ and low phosphate (3). In vitro the action of 1,25 -dihydroxyvitamin $D_{3}$ can be enhanced by retinoic acid (6). The stimuli to PT cell hyperplasia are less well defined.

Parfitt (1) has analyzed the literature on PT cell replication, and concluded that after cessation of growth, few PT cells divide more than twice, and many do not divide at all. He suggested that since the adult PT cell number does not change, the very slow rate of cell gain must be balanced by a correspondingly slow rate of cell loss (1). The parathyroid normally has very few mitoses but it has the potential to replicate after stimuli such as a chronically low serum calcium (2). An analogous situation might be the adrenal cortex which becomes hyperplastic after chronic stimulation with its trophic hormone, adrenal cortical trophic hormone (ACTH), or the thyrotrophic cells of the pituitary which become hyperplastic after thyroidectomy without thyroxin replacement therapy. This indicates that these cells retain a stem cell potential which is normally not expressed. Stereoscopic electron microscopy studies have shown that the parathyroid cells of rats fed a low calcium diet for 3 wk are hypertrophied $(7,8)$, and flow cytometry estimation of parathyroid cell number showed that there was a large increase in PTH gene expression per cell and only a moderate increase in parathyroid cell number (2). However, patients with chronic renal failure are maintained on hemodialysis treatment for years and in this situation the parathyroid cell hyperplasia becomes a major clinical problem resulting in the synthesis of large amounts of PTH $(9,10)$. This excess PTH leads to tremendous bone resorption, osteitis fibrosa cystica, which is a central feature of renal osteodystrophy. It is therefore of prime clinical importance to understand the pathogenesis of PT cell hyperplasia and to determine what causes the PT cell to proliferate.

The onset of DNA replication and mitosis, the two key cellcycle events is a tightly controlled event. In yeast and eukaryotic cells in culture there is a cascade of cyclins $(D, E, A, B)$ which are sequentially activated to take the cell through the different phases of the cell cycle. Their activity is in balance with those of cyclin kinase inhibitors, such as p27 and p21, and when the activities of the different cyclin kinases exceed that of the inhibitors then the cell enters the cell cycle (11). The human nuclear protein, proliferating cell nuclear antigen (PCNA), so

1. Abbreviations used in this paper: PCNA, proliferating cell nuclear antigen; PT, parathyroid; TUNEL, terminal deoxynucleotidyl transferase (TdT) -mediated dUTP-biotin nick end labeling. 
named because of its initial discovery as a cell-cycle dependent antigen (12), is a cofactor of DNA polymerase $\delta(13)$. PCNA is important in cellular DNA synthesis and in cell cycle progression where it acts as a processivity factor or sliding clamp for DNA polymerase $\delta(14)$. Crystal structure of PCNA shows that three PCNA molecules encircle duplex DNA, providing a DNAbound platform for the attachment of the polymerase (15) Antisense oligonucleotides to PCNA added to exponentially growing Balb/c3T3 cells completely suppressed their growth (16). When cells enter the cell cycle and are proliferating their nuclei stain positively for PCNA and this immunohistochemical test is now a sensitive test for cell proliferation in histology sections (17). We have used PCNA staining to characterize the regulators of cell proliferation in the parathyroid from rats fed diets with different amounts of calcium, phosphate and vitamin $\mathrm{D}$, both in normal rats and rats with chronic renal failure due to 5/6 nephrectomy. The results show that in those situations where there is an increase in PTH mRNA and serum PTH, such as hypocalcemia, hyperphosphatemia and chronic renal failure, there was an increase in PT cell proliferation. In an experimental model where there is a decrease in PTH mRNA due to hypophosphatemia there was a complete absence of proliferation, however, after $1,25(\mathrm{OH})_{2} \mathrm{D}_{3}$ at a dose which decreased PTH mRNA there was no change in the number of proliferating PT cells.

Programmed cell death or apoptosis is associated with endogenous endonuclease activity which results in the cleavage of chromatin at linker DNA sites between nucleosomes (18, 19). The ultimate DNA fragments are 180-bp nucleosomal units which appear as "DNA laddering" in standard agarose gels of DNA extracted from apoptotic cells. Gavrielli et al. (20) have developed a method for the in situ labeling of DNA breaks in nuclei in tissue sections at the single cell level while preserving tissue architecture. The method is based on the specific binding of terminal deoxynucleotidyl transferase (TdT) to 3 '-OH ends of DNA and incorporating biotinylated deoxyuridine at sites of DNA breaks. The signal is amplified by avidin-peroxidase and identified by light microscopy. We applied the method of TdTmediated dUTP-biotin nick end labeling (TUNEL) to the PT tissue from rats with dietary hyper- and hypoparathyroidism and after $1,25(\mathrm{OH})_{2} \mathrm{D}_{3}$ administration and in no situations were there PT cells undergoing apoptosis as measured by positive TUNEL staining.

\section{Methods}

\section{Animals}

Weanling male Hebrew University strain rats were maintained for 3 wk on the following diets (Teklad, IL): Low phosphate, normal calcium ( $0.02 \%$ phosphate, $0.6 \%$ calcium); normal phosphate, normal calcium ( $0.3 \%$ phosphate, $0.6 \%$ calcium); high phosphate, high calcium $(1.2 \%$ phosphate, $1.2 \%$ calcium); vitamin $\mathrm{D}$ deficient, low calcium $(0.02 \%$ calcium). After 1 to $21 \mathrm{~d}$ the thyroparathyroid tissue was excised under pentobarbital anesthesia, and blood samples taken. All rat surgery was performed at 9-10 am. The excised tissue was immediately frozen in liquid nitrogen and stored at $-70^{\circ} \mathrm{C}$ for RNA extraction, or fixed in $4 \%$ paraformaldehyde and paraffin blocks prepared for histological analysis. $5 / 6$ nephrectomy (5/6NX) was performed on 180-220 gram male rats in a two-stage procedure under ether anesthesia as previously reported (21). The $5 / 6$ nephrectomized rats were then fed diets with different phosphate contents as above for two weeks after the second operation.

Measurement of cellular mRNA levels

RNA was extracted from rat thyroparathyroid tissue and the levels of PTH mRNA were measured by Northern blots after extraction with TRI
Reagent (Molecular Research Center Inc., Cincinnati, Ohio). RNA was denatured and ethidium bromide was added to each sample at a concentration of $0.1 \mathrm{mg} / \mathrm{ml}$. The samples were size-fractionated by electrophoresis on $1.25 \%$ agarose gels containing formaldehyde and transferred to Hybond filters (Amersham, England) by diffusion blotting. The integrity of the RNA and the uniformity of RNA transfer to the membrane were determined by UV visualization of the ribosomal RNA bands of the gels and the filters. The filters were fixed by UV cross-linking and hybridized as previously described $(4,5)$. Hybridization was to a random primed rat PTH cDNA (a gift of H. Meyer, GBF, Braunschweig, Germany) and 18S RNA (gift of M. A. Levine, Baltimore, MD).

\section{Immunohistochemistry}

Proliferating cell nuclear antigen (PCNA). Paraffin tissue blocks were cut to 4-6-mm-thick sections, deparaffinized in xylene and alcohols, and placed for $15 \mathrm{~min}$ in alcohol- $\mathrm{H}_{2} \mathrm{O}_{2}, 3 \%$, for blocking endogenous peroxidase. To reveal masked antigens in formalin-fixed, paraffin-embedded tissue sections, slides were placed in citrate buffer ( $\mathrm{pH} 6.0$ ) and treated in the microwave at $92^{\circ} \mathrm{C}$ for $10 \mathrm{~min}$. After removing container from the microwave and cooling for $15 \mathrm{~min}$, slides were placed in PBS ( $\mathrm{pH}$ 7.6). Sections were then treated with Bovine Serum Albumin (BSA) to prevent background staining, and incubated for one hour with the primary antibody PCNA-PC-10 (Zymed Laboratories, Inc., San Francisco, CA) at room temperature in a humidified chamber $(22,23)$. Slides were rinsed with PBS for 3-4 min and incubated with the biotinylated linked antibody for $30 \mathrm{~min}$ and with the labeling reagent peroxidase conjugated streptavidin for $30 \mathrm{~min}$ (Bio Genex Laboratories, San Ramon, CA). After rinsing, the peroxidase label was demonstrated using 3-amino-9-ethyl carbazole (AEC) for $15 \mathrm{~min}$, and counterstained with Mayer Hematoxylin. AEC produces a red end-product that is soluble in alcohol and is used with an aqueous mounting media (kaiser's glycerol gelatin). A negative control was run using the same technique but omitting the primary antibody and adding the streptavidin-biotin complex. PCNA positive cells were counted per microscope field with the PT section completely filling the microscope field. For each rat four microscope fields were counted and the mean used. The variation amongst sections in each rat was always $<10 \%$. Each group represents the mean $\pm S E M$ of $4-5$ rats.

\section{DNA nick end labeling of tissue sections}

This was performed essentially as described (20). Tissue sections were treated with proteinase $\mathrm{K}$, washed four times, treated with $2 \% \mathrm{H}_{2} \mathrm{O}_{2}$, rinsed and immersed in buffer with biotinylated dUTP and rinsed. The sections were covered with Extra-avidin peroxidase (BioMakor, Rehovot, Israel), washed and stained with AEC for $30 \mathrm{~min}$ (20).

\section{Serum measurements}

Serum calcium and phosphate were measured in a Roche autoanalyzer. Serum $1,25(\mathrm{OH})_{2} \mathrm{D}_{3}$ levels were measured by a radioreceptor assay (Incstar, Minneapolis, MN). Serum iPTH levels were measured with a rat immunoradiomimetric assay (Nichols, San Clemente, CA). Statistical analysis was performed on the Macintosh program Statview 512+, using Student's unpaired two-tailed $t$ test. The results are presented as the mean \pm SEM.

\section{Results}

Table I shows the serum biochemistry in the weanling rats fed the different diets for $3 \mathrm{wk}$. Serum calcium was decreased in the rats fed a low calcium diet and increased in rats fed a low phosphate diet. Serum phosphate only changed in the rats fed a low phosphate diet where it was decreased. Serum $1,25(\mathrm{OH})_{2} \mathrm{D}_{3}$ was markedly increased in rats fed both the low calcium and the low phosphate diets, and decreased by the high phosphate diet.

PTH mRNA levels were increased in the rats fed the low 
Table I. The Effects of 3 wk of Diet Given to Weanling Rats

\begin{tabular}{lccc}
\hline \multicolumn{1}{c}{ Diet } & $\begin{array}{c}\text { Serum calcium } \\
(\text { mean } \pm \text { SE) }\end{array}$ & $\begin{array}{c}\text { Serum phosphate } \\
(\text { mean } \pm \text { SE) }\end{array}$ & $\begin{array}{c}\text { Serum } \\
1,25(\mathrm{OH})_{2} \mathrm{D}_{3} \\
(\text { mean } \pm \mathrm{SE})\end{array}$ \\
\hline Control & $m g / d l$ & $m g / d l$ & $p g / m l$ \\
Low calcium & $10.6 \pm 0.6$ & $9.8 \pm 1.2$ & $68.0 \pm 28.3$ \\
Low phosphate & $6.8 \pm 0.1^{\ddagger}$ & $9.9 \pm 0.5$ & $>400^{\ddagger}$ \\
High phosphate & $12.6 \pm 0.6^{*}$ & $4.0 \pm 0.4^{\ddagger}$ & $>400^{\ddagger}$ \\
& $11.1 \pm 0.6$ & $9.4 \pm 0.8$ & $30.0 \pm 5.9^{*}$ \\
\hline
\end{tabular}

Four rats in each group. $* P<0.05$ and ${ }^{\ddagger} P<0.01$ compared with control diet.

calcium diet and markedly decreased in the rats fed a low phosphate diet (Fig. 1) with no changes in a control gene 18 S RNA (not shown) and as previously reported $(2,3)$. PCNA staining of thyroparathyroid tissue showed that there were $\sim 10$ PCNA positive cells per microscope field in the PTs of a control rat $10 \mathrm{~d}$ after weaning and there was a sixfold increase in weanling rats fed a low calcium diet for $10 \mathrm{~d}$ (Figs. 2 and 3). After 21 $\mathrm{d}$ of diet there was a smaller number of PCNA positive cells in the control rats $(P<0.05)$ as compared with rats at $10 \mathrm{~d}$ after weaning and those rats on a low calcium diet had a 3.6fold increase in PCNA positive cells (Figs. 2 and 3). After a low phosphate diet for $21 \mathrm{~d}$ there were no PCNA positive cells at all (Figs. 2 and 3) as well as a marked decrease in PTH mRNA levels (Figs. 1 and 3 ). Rats fed a high phosphate diet had a moderate increase in PTH mRNA levels (Figs. 1 and 3) and more PCNA positive cells than the controls, but not nearly as much as rats fed a low calcium diet (Fig. 3).

5/6 Nephrectomized rats have increased PTH mRNA levels as compared with control rats (21). A high phosphate diet did not increase serum phosphate (Table II) or PTH mRNA levels significantly (Fig. 4). A low phosphate diet led to a decrease in serum phosphate and an increase in serum calcium (Table II) and with this there was a marked decrease in PTH mRNA levels (Fig. 4). There was no change in a control gene $18 \mathrm{~S}$ RNA (not shown). Serum $1,25(\mathrm{OH})_{2} \mathrm{D}_{3}$ levels were increased by a low phosphate diet (95 \pm : $165 \pm 12 \mathrm{pg} / \mathrm{ml}$; control: low phosphate; mean \pm SE $(n=4), P<0.01)$. PCNA staining of parathyroid tissue from these rats showed a small number of positive cells in control mature rats with normal renal function, an increased number of PCNA positive cells in 5/6 nephrectomized rats fed a control diet and this was further increased by a high phosphate diet (Figs. 5 and 6 ). The $5 / 6$ nephrectomized rats fed a low phosphate diet had a marked reduction in the number of PCNA positive cells to numbers even less than control rats with normal renal function (Figs. 5 and 6).

PTH mRNA levels were reduced by injecting rats with $1,25(\mathrm{OH})_{2} \mathrm{D}_{3}$ (3 daily injections of $25 \mathrm{pmol}$ ) at $21 \mathrm{~d}$ after weaning and studied $24 \mathrm{~h}$ later. Their serum biochemistry showed that there were no changes in serum calcium $\left(10.2 \pm 0.2: 10.6 \pm 0.2 \mathrm{mg} / \mathrm{dl}\right.$, control: $\left.1,25(\mathrm{OH})_{2} \mathrm{D}_{3} ; \mathrm{P} \mathrm{NS}\right)$ or phosphate $\left(10.2 \pm 0.3: 10.5 \pm 0.3 \mathrm{mg} / \mathrm{dl}\right.$, control: $1,25(\mathrm{OH})_{2} \mathrm{D}_{3}$; P NS) but $1,25(\mathrm{OH})_{2} \mathrm{D}_{3}$ led to a decrease in PTH mRNA levels

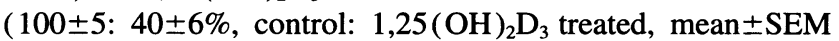
$(n=5), P<0.01)$ as previously reported (5). There was no change in the number of PCNA staining positive cells (Fig. 2). Therefore, in this situation where there was a decrease in PTH

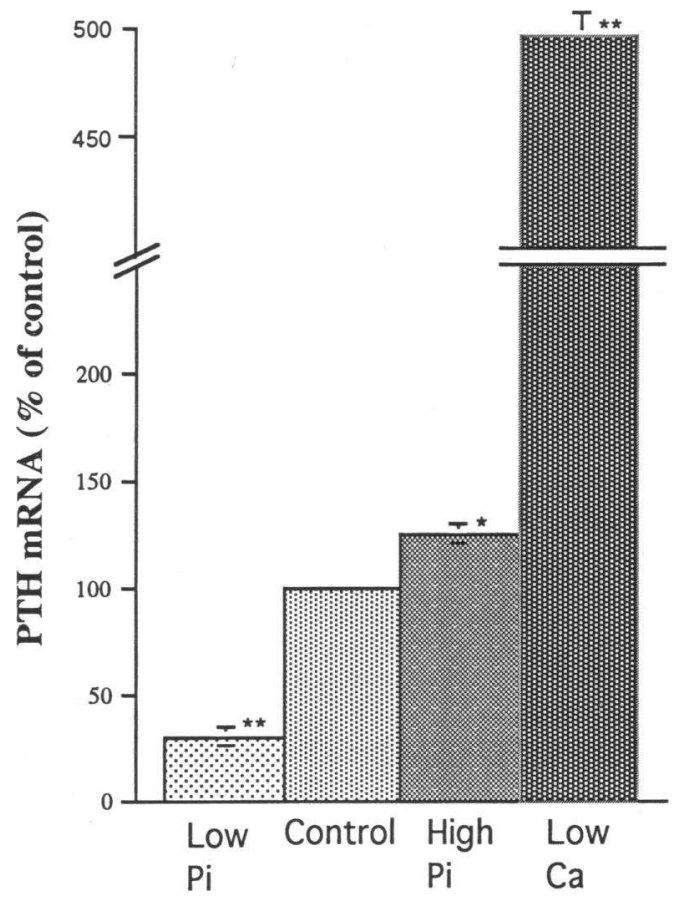

Figure 1. The effect of dietary phosphate and calcium on PTH mRNA levels. Results are shown for weanling rats fed diets for three weeks containing low phosphate $(0.02 \%)$; control; high phosphate $(1.2 \%)$; low calcium $(0.02 \%)$; as mean \pm SEM for four rats and compared to rats fed the control diet. $* P<0.05 ; * * P<0.01$

mRNA levels there was no decrease in the number of proliferating cells. This experiment therefore showed that there was no direct relationship between PTH mRNA levels and PCNA positive cells.

In many situations where there is accelerated cell proliferation there is a corresponding accelerated cell apotosis such as in the small intestine. We therefore studied whether there were PT cells undergoing apoptosis in these experimental models of dietary hyper- and hypoparathyroidism. Rats fed diets with a low calcium, low and high phosphate as well as rats after three daily injections of $1,25(\mathrm{OH})_{2} \mathrm{D}_{3}$ ( 25 pmol daily) were studied. In all the groups studied there were no apoptotic cells seen by the TUNEL method (not shown). As a control for the accuracy of the TUNEL method small intestine from normal rats and malignant melanoma and breast cancer tissues were studied at the same time. They all showed the expected number of apoptotic cells (20). Therefore, the PT gland is characterized by the ability to respond by increasing or decreasing PTH gene expression, PTH secretion and PT cell proliferation. There was no evidence of PT cell programmed cell death as measured by the TUNEL method after changes in dietary calcium and phosphate and injections of $1,25(\mathrm{OH})_{2} \mathrm{D}_{3}$ in the present experiments. The TUNEL method is reported to be an accurate measure of DNA nicks present in apoptotic cells but the classic definition of apoptosis is by morphology which was not studied here.

\section{Discussion}

PCNA staining of nuclei is a sensitive and reliable index of the $\mathrm{S}$ phase of cell proliferation which is now routinely used in the 

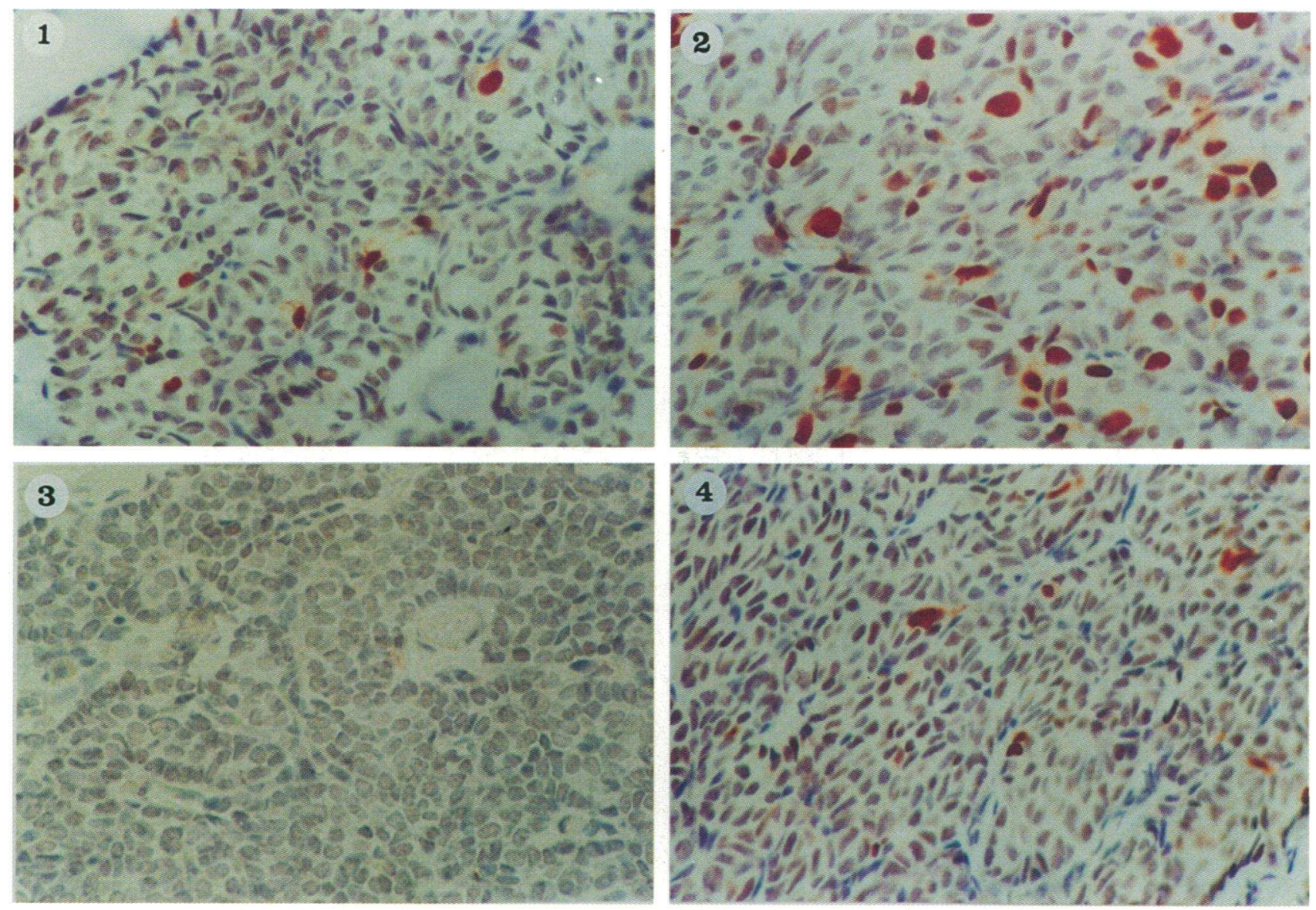

Figure 2. PCNA staining of parathyroid tissue from rats fed diets with a low calcium or phosphate, or after treatment with $1,25(\mathrm{OH})_{2} \mathrm{D}_{3}$. PCNApositive nuclei are stained red. (1) a control rat $10 \mathrm{~d}$ after weaning; (2) a rat fed a low calcium diet for $10 \mathrm{~d}$; (3) a rat fed a low phosphate diet for $21 \mathrm{~d} ;(4)$ a rat injected ip with $1,25(\mathrm{OH})_{2} \mathrm{D}_{3}(25 \mathrm{pmol} / \mathrm{d}$ for $3 \mathrm{~d})$.

study of human pathology specimens (17). Previous studies on PT cell hyperplasia have used relatively insensitive techniques such as counting mitoses (24) or flow cytometry determination of PT cell number after dispersion of PT glands into single cells (2). The PCNA staining provides a sensitive and reproducible measurement of PT cell proliferation although a possible limitation of the methodology is that it may also measure DNA repair. Dietary hypocalcemia leads to secondary hyperparathyroidism with marked increases in PTH mRNA and serum PTH levels (2). In the present study there was the same increase in PTH mRNA and with this there was an increase in PT cell proliferation as measured by PCNA at both 10 and $21 \mathrm{~d}$. Rats fed a high phosphate diet have a moderate increase in their PTH mRNA levels and with this a small but significant increase in their PCNA positive cells. A low phosphate diet leads to a decrease in PTH mRNA and serum PTH levels (3) and the effect on PTH mRNA was confirmed in this study, and what was most dramatic was the tremendous decrease in PCNA positive cells with this diet. There were no proliferating PT cells as measured by PCNA in rats fed a low phosphate diet. Hypophosphatemic rats have other characteristics such as hypercalcemia and increased serum $1,25(\mathrm{OH})_{2} \mathrm{D}_{3}$ levels which may also be relevant to the decrease in PT cell proliferation. Control rats 10 and 21 $\mathrm{d}$ after weaning had between 6 and 10 PCNA positive cells per field (Figs. 2 and 3 ). Control mature rats $( \pm 300$ gram body weight) had 2-3 positive cells per field (Figs. 5 and 6 ). Mature rats with experimental chronic renal failure due to a $5 / 6$ nephrectomy have an increase in PTH mRNA indicating secondary hyperparathyroidism (21) and a fivefold increase in PCNA positive cells. Uremic rats fed a high phosphate diet had an increase in PCNA positive cells but no increase in PTH mRNA. 5/6 Nephrectomy rats fed a low phosphate diet had a marked decrease in PTH mRNA levels as well as a dramatic decrease in PCNA positive cells. Therefore, in all these models where PTH mRNA was increased or decreased there was a corresponding increase or decrease in PCNA positive cells. This raises the question whether the same process that regulates PTH gene expression and secretion is involved in the regulation of PT cell proliferation. However, rats injected with $1,25(\mathrm{OH})_{2} \mathrm{D}_{3}$ had the expected decrease in PTH mRNA levels (5) with no effect on PT cells staining positively for PCNA. Therefore in this experimental model PTH gene expression was decreased and PT cell proliferation was not affected, showing that the signal for proliferation may be separated from that for PTH gene expression. Both hypocalcemic and hypophosphatemic rats have high levels of serum $1,25(\mathrm{OH})_{2} \mathrm{D}_{3}$ but hypocalcemic rats have an increased number of PCNA positive cells and hypophosphatemic rats have a decreased number. This indicates that in these models the effect of calcium and phosphate have a dominant effect on PT cell proliferation over that of $1,25(\mathrm{OH})_{2} \mathrm{D}_{3}$. Modest and brief elevations of serum $1,25(\mathrm{OH})_{2} \mathrm{D}_{3}$ did not affect PT cell proliferation but decreased PTH gene expression. 


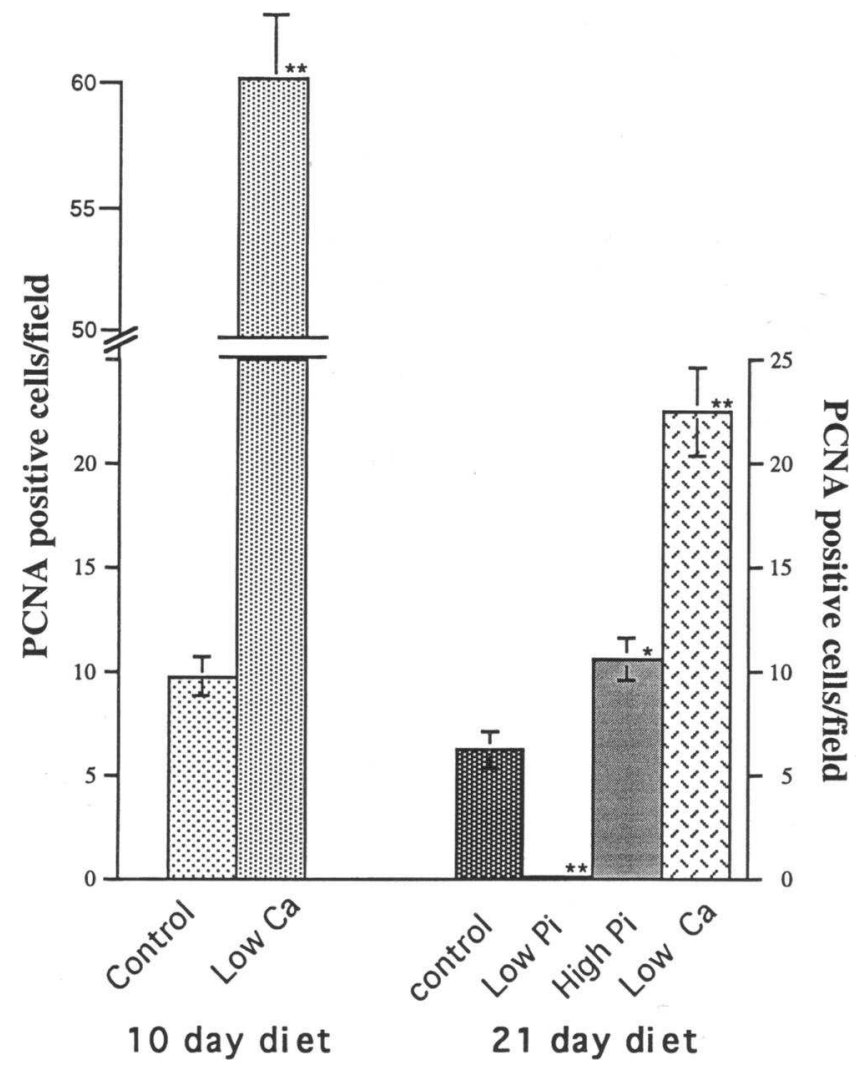

Figure 3. Dietary phosphate and calcium regulate parathyroid cell proliferation. Weanling rats were fed different diets for 10 or $21 \mathrm{~d}$ and the number of proliferating cells determined by PCNA staining. The diets were either control, low calcium $(0.02 \%)$, low phosphate $(0.02 \%)$, or high phosphate $(1.2 \%)$. The results are expressed as PCNA positive cells per microscope field, as mean $\pm \mathrm{SE}$ for four different rats and compared to rats fed the control diet; $* P<0.05 ; * * P<0.01$.

Cell size was not measured in the present studies but it is apparent in the photographs demonstrating the presence of PCNA (Figs. 2 and 5) that hypocalcemia was associated with large hypertrophied cells as documented by Wernerson et al. $(7,8)$, and hypophosphatemia with smaller PT cells. PT cell hypertrophy may be a stage in the path to cell division.

There are many other differences between the mechanisms by which calcium and phosphate regulate PTH mRNA levels compared to $1,25(\mathrm{OH})_{2} \mathrm{D}_{3}$. Firstly, $1,25(\mathrm{OH})_{2} \mathrm{D}_{3}$ is a sterol

Table II. The Effects of 3 wk of Diets Given to 5/6 Nephrectomized (NX) Rats

\begin{tabular}{lccc}
\hline \multicolumn{1}{c}{ Diet } & $\begin{array}{c}\text { Serum creatinine } \\
(\text { mean } \pm \text { SE) }\end{array}$ & $\begin{array}{c}\text { Serum calcium } \\
(\text { mean } \pm \text { SE) }\end{array}$ & $\begin{array}{c}\text { Serum phosphate } \\
(\text { mean } \pm S E)\end{array}$ \\
\hline & $m g / d l$ & $m g / d l$ & $m g / d l$ \\
Control & $0.5 \pm 0.03^{*}$ & $11.1 \pm 0.8$ & $10.3 \pm 0.2^{*}$ \\
$5 / 6 \mathrm{NX}$ & $0.83 \pm 0.03$ & $11.0 \pm 0.1$ & $9.2 \pm 0.4$ \\
5/6NX low phosphate & $0.82 \pm 0.05$ & $14.0 \pm 0.3^{*}$ & $3.2 \pm 0.2^{\ddagger}$ \\
5/6NX high phosphate & $0.79 \pm 0.1$ & $11.6 \pm 0.2^{*}$ & $9.7 \pm 0.7$ \\
& & & \\
\hline
\end{tabular}

There were four rats in each group. ${ }^{*} P<0.05$ and ${ }^{\ddagger} P<0.01$ compared with $5 / 6 \mathrm{NX}$ control diet.

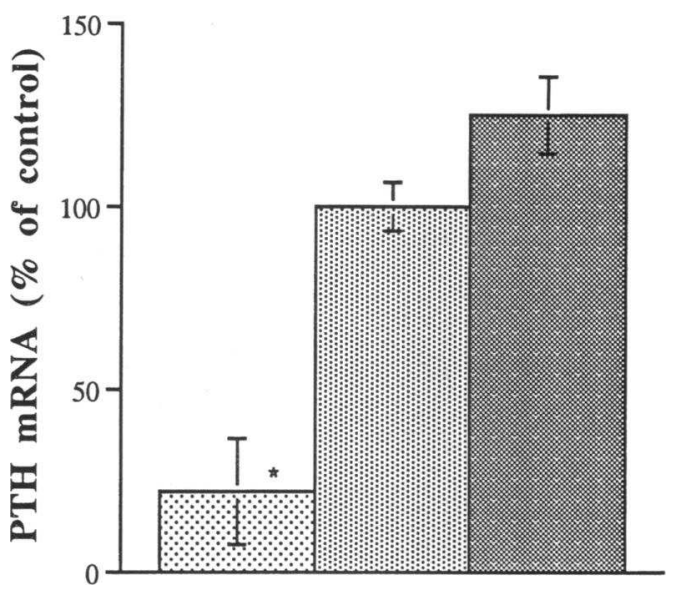

Figure 4. The effect of dietary phosphate and calcium on PTH mRNA levels in 5/6 nephrectomized (CRF) rats fed diets containing low phosphate; control; high phosphate. Results are shown for rats on diets as mean \pm SEM for four rats and compared to rats fed the control diet. ${ }^{*} P$ $<0.01$.

hormone and has a transcriptional effect on the PTH gene both in vivo and in vitro $(5,25)$. In vivo both calcium and phosphate have a post-transcriptional effect $(3,26)$. In vitro a calcium responsive element has been characterized in the PTH gene suggesting a transcriptional role but its physiological relevance has not been determined (22). Calcium regulates the PT cell by binding to a calcium sensor on the cell membrane which activates phospholipase $\mathrm{C}$ (27), and it is not known by what mechanism phosphate regulates the PT cell. It might be directly or indirectly via a factor which is not serum calcium or $1,25(\mathrm{OH})_{2} \mathrm{D}_{3}(3)$. In any event the present study clearly shows that hypocalcemic rats have an increased PT cell proliferation and hypophosphatemic rats a decreased PT cell proliferation. These findings are relevant to the pathogenesis of secondary hyperparathyroidism and its treatment. Transient increases in intracellular calcium may have a role in the progression of the cell through mitosis possibly mediated by changes in calmodulin concentration (28), but what is of particular interest in our present study on the PT is that the stimulus to proliferation was a low serum calcium and this has been shown to be associated with a decrease in intracellular calcium in the PT (29).

In tissues with a high proliferation index such as small intestine or dormant metastases there is a steady state where cell proliferation is balanced by cell death $(30)$. Cell death could be a result of necrosis which was not observed in parathyroids or programmed cell death. Programmed cell death or apoptosis differs from necrosis in that it is characterized by single cell death in the midst of living cells (19). Apoptosis was studied in situ at a cellular level by labeling fragmented DNA with the terminal deoxynucleotidyl transferase (TdT) labeling technique (20). There were no apoptotic cells in the parathyroids from rats with secondary hyperparathyroidism due to a low calcium diet, experimental renal failure or a high phosphate diet. There were also no cells undergoing apoptosis in the parathyroids of rats with secondary hypoparathyroidism due to a low phosphate diet nor in those injected with $1,25(\mathrm{OH})_{2} \mathrm{D}_{3}$. Tissues with known apoptosis such as the small intestine, melanoma and breast cancer were studied at the same time and they had their expected apoptotic indices. Therefore, in these 

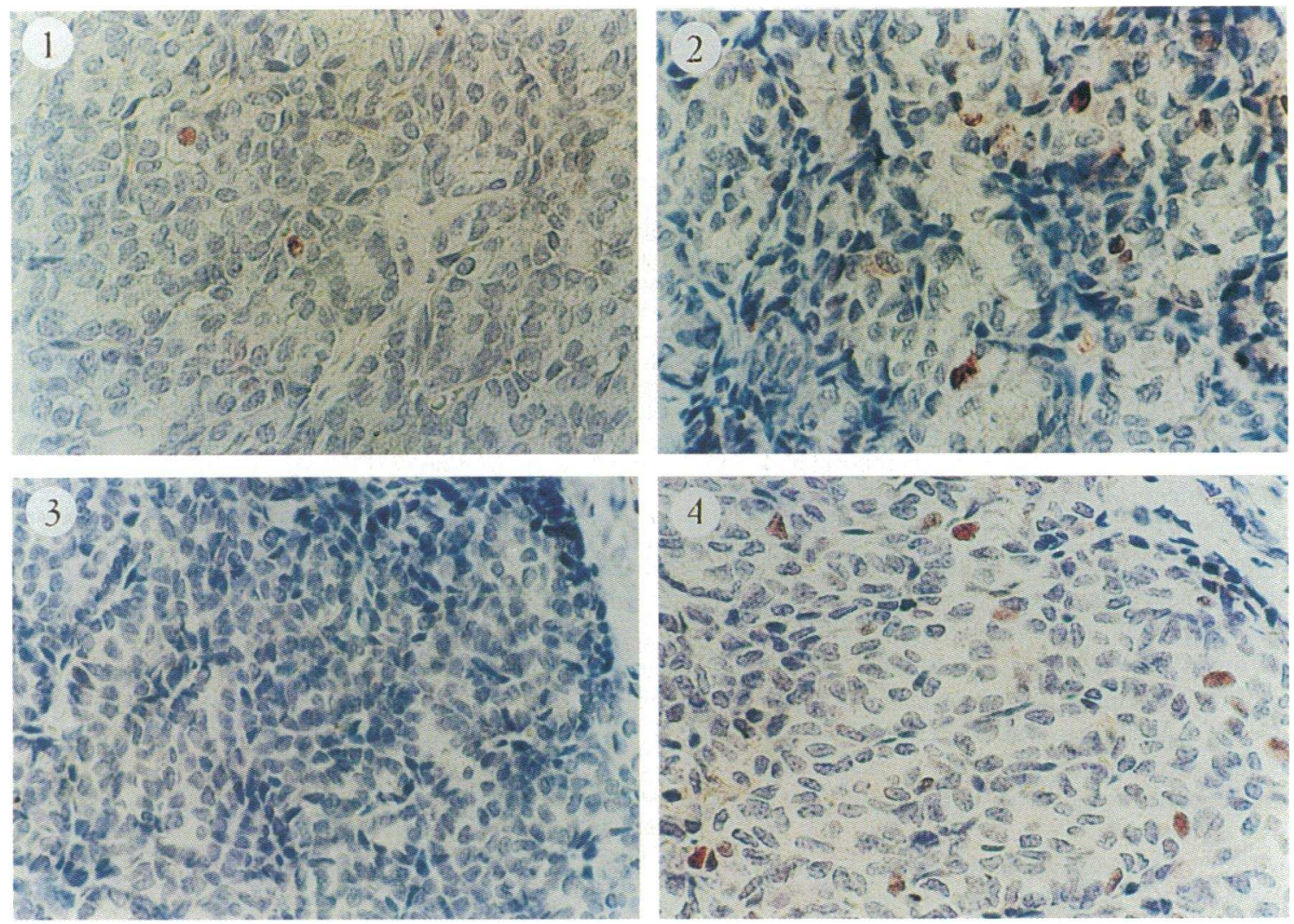

Figure 5. PCNA staining of parathyroid tissue from a control rat and 5/6 nephrectomized rats fed different diets for 2 wk. Nuclei of PCNA positive cells are stained red. (1) a control rat; (2) a 5/6 nephrectomized rat fed a normal diet; (3) a $5 / 6$ nephrectomized rat fed a low phosphate diet; (4) a 5/6 nephrectomized rat fed a high phosphate diet.

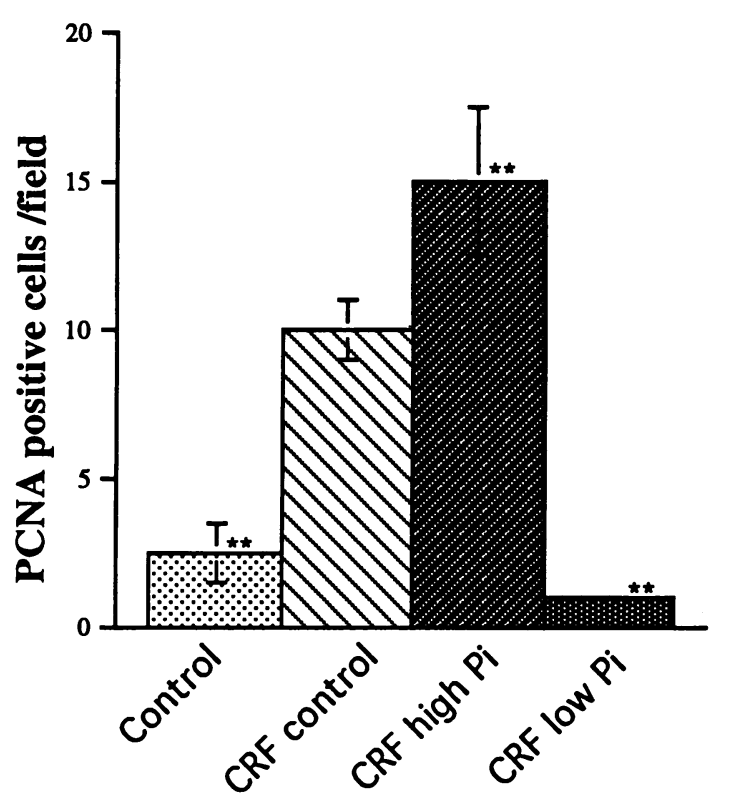

Figure 6. Chronic renal failure (CRF) increases parathyroid cell proliferation and this is further increased by a high phosphate diet and decreased by a low phosphate diet. Mature rats underwent $5 / 6$ nephrectomy and were fed normal, low or high phosphate diets before study. The number of PCNA positive cells per microscope field was counted. The results are shown as mean $\pm \mathrm{SE}$ for four different rats, and the number of PCNA positive cells compared to the control CRF rats; **P $<0.01$. experimental conditions with different effects on PT cell proliferation there were no PT cells which stained positive for apoptosis by the TUNEL method. The TUNEL method measures DNA fragments which are present in apoptotic cells, but the classic definition of apoptosis is morphologic. It is possible that histological studies would have detected apoptotic cells not detected by the staining method used here. Patients with chronic stimuli for PT cell proliferation should have careful attention paid to a normal serum calcium and phosphate in order to prevent the PT cell hyperplasia which these studies show is largely an irreversible process.

The mechanism of how hypocalcemia leads to an increase in PT cell proliferation and PT hyperplasia is not known. Studies in vitro with primary cultures of bovine parathyroid cells have shown an effect of low calcium to increase PT cell mitoses as measured by $\left[{ }^{3} \mathrm{H}\right]$ thymidine incorporation $(31-33)$ but it has recently been shown that bovine PT cells in culture lose the calcium sensor mRNA and protein (34) and therefore it is not clear if the effect observed is mediated by a physiological transduction pathway. However, it is possible that there are other calcium sensors in the PT which may have recognized the changes in extracellular calcium concentration. PT cell hyperplasia is an important component of the secondary hyperparathyroidism of both chronic renal failure and chronic hypocalcemia. The chronic hypocalcemia may be the result of one of a number of causes, such as dietary calcium depletion as in intestinal malabsorption (35) or in patients with X-linked hypophosphatemia chronically over-treated with oral phosphate (36). In chronic renal failure the different factors which may have a role in the secondary hyperparathyroidism are hypocal- 
cemia, hyperphosphatemia and vitamin D deficiency. The common feature of these different clinical conditions is a chronically low serum calcium. Some patients would also have an increased serum phosphate such as after chronic phosphate therapy in Xlinked hypophosphatemia and patients with renal failure. It has been suggested that $1,25(\mathrm{OH})_{2} \mathrm{D}_{3}$ decreases PT cell replication $(24,37)$ analogous to its effect on cells such as HL60 in tissue culture (38). However, patients with X-linked hypophosphatemia who would have low endogenous serum $1,25(\mathrm{OH})_{2} \mathrm{D}_{3}$ levels have been treated chronically with high doses of $1,25(\mathrm{OH})_{2} \mathrm{D}_{3}$ for years and despite the $1,25(\mathrm{OH})_{2} \mathrm{D}_{3}$ treatment have developed large hyperplastic parathyroids that have required treatment with parathyroidectomy (36). In all these clinical situations the stimulus was hypocalcemia but hyperphosphatemia may have an independent role. Serum phosphate is invariably raised in chronic renal failure and correction of serum phosphate alone with no changes in serum calcium or $1,25(\mathrm{OH})_{2} \mathrm{D}_{3}$ corrects secondary hyperparathyroidism (39-41) and it is possible but not proven that phosphate may have a direct effect on the PT cell similar to that of calcium (3). In patients with intestinal malabsorption both the serum calcium and $1,25(\mathrm{OH})_{2} \mathrm{D}_{3}$ levels would be decreased. Therefore, chronic hypocalcemia is the one recognized factor which is shared by these different clinical conditions which lead to parathyroid cell hyperplasia.

The mechanisms of PT cell proliferation in primary hyperparathyroidism and in some PT adenomas $(42,43)$ and all PT carcinomas (44) have been elucidated and they may be relevant to the development of secondary or more likely tertiary hyperparathyroidism (45). Primary hyperparathyroidism may result from a number of different molecular mechanisms such as in patients with familial hypocalciuric hypercalcemia (FHH) (46, 47) where there is a mutation in the gene coding for the PT calcium sensor (48), or in multiple endocrine neoplasia where the clonal proliferating PT cells contain deletions on the long arm of chromosome 11 (type 1$)(49,50)$, or inherited mutations in the RET oncogene (type 2) (51-53). These inherited molecular changes are associated with hyperplasia of all four PT glands similar to the secondary hyperplasia of chronic renal failure. Most hemodialysis patients with uremic refractory hyperparathyroidism were shown by Arnold et al to have at least one monoclonal parathyroid tumor (54), which suggests that neoplastic transformation of preexisting polyclonal hyperplasia may have led to these monoclonal growths (54).

Therefore, the PT cell may be stimulated to proliferate under appropriate physiological stimuli such as a low serum calcium, and pathological stimuli such as a genetic alteration in mediators of signal transduction, the cell cycle or absence of a tumor suppressor gene where it has the potential to proliferate and even transform into a malignant cell. It is these lessons which are now being applied to an understanding of PT cell proliferation in the secondary hyperparathyroidism of chronic renal failure in order to design effective preventative and therapeutic measures.

\section{Acknowledgments}

Ms. Miriam Offner for excellent technical assistance. S. Edelstein of the Weizmann Institute for performing the serum $1,25(\mathrm{OH})_{2} \mathrm{D}_{3}$ assays. This work was supported by the Thyssen Foundation.

\section{References}

1. Parfitt, A. M. 1994. Parathyroid growth, normal and abnormal. In The Parathyroids. J. P. Bilezikian, M. A. Levine, and R. Marcus, editors. Raven Press, Ltd., New York. 373-405.

2. Naveh-Many, T., and J. Silver. 1990. Regulation of parathyroid hormone gene expression by hypocalcemia, hypercalcemia, and vitamin $\mathrm{D}$ in the rat. $J$. Clin. Invest. 86:1313-1319.

3. Kilav, R., J. Silver, and T. Naveh-Many. 1995. Parathyroid hormone gene expression in hypophosphatemic rats. J. Clin. Invest. 96:327-333.

4. Naveh-Many, T., G. Almogi, N. Livni, and J. Silver. 1992. Estrogen receptors and biologic response in rat parathyroid tissue and C-cells. J. Clin. Invest. 90:2434-2438.

5. Silver, J., T. Naveh-Many, H. Mayer, H. J. Schmelzer, and M. M. Popovtzer. 1986. Regulation by vitamin $D$ metabolites of parathyroid hormone gene transcription in vivo in the rat. J. Clin. Invest. 78:1296-1301.

6. MacDonald, P. N., C. Ritter, A. J. Brown, and E. Slatopolsky. 1994. Retinoic acid suppresses parathyroid hormone (PTH) secretion and PreproPTH mRNA levels in bovine parathyroid cell culture. J. Clin. Invest. 93:725-730.

7. Svensson, O., A. Wernerson, and F. P. Reinholt. 1988. Effect of calcium depletion on the rat parathyroids. Bone. Miner. 3:259-269.

8. Wernerson, A., S. M. Widholm, O. Svensson, and F. P. Reinholt. 1991. Parathyroid cell number and size in hypocalcemic young rats. APMIS. 99:10961102.

9. Castleman, B., and T. B. Mallory. 1937. Parathyroid hyperplasia in chronic renal insufficiency. Am. J. Pathol. 13:553-574.

10. Silver, J. 1991. Regulation of the synthesis and secretion of parathyroid hormone. In Disorders of Bone and Mineral Metabolism. M. J. Favus and F. L. Coe, editors. Raven Press, New York.

11. Peters, G. 1994. Stifled by inhibitions. Nature (Lond.). 371:204-205.

12. Miyachi, K., M. J. Fritzler, and E. M. Tan. 1978. Autoantibody to nuclear antigen in proliferating cells. J. Immunol. 121:2228-2234.

13. Almendral, J. M., D. Huebsch, P. A. Blundell, H. Macdonald-Bravo, and R. Bravo. 1987. Cloning and sequence of the human nuclear protein cyclin: homology with DNA-binding proteins. Proc. Natl. Acad. Sci. USA. 84:15751579.

14. Kornberg, A., and T. A. Baker. 1991. DNA replication. W. H. Freeman, New York.

15. Krishna, T. S. R., X.-P. Kong, S. Gary, P. M. Burgers, and J. Kuriyan 1994. Crystal structure of the eukaryotic DNA polymerase processivity factor PCNA. Cell. 79:1233-1243.

16. Jaskulski, D., J. K. deRiel, W. E. Mercer, B. Calabretta, and R. Baserga. 1988. Inhibition of cellular proliferation by antisense oligodeoxynucleotides to PCNA cyclin. Science (Wash. DC). 240:1544-1546.

17. Galand, P., and C. Degraef. 1989. Cyclin/PCNA immunostaining as an alternative to tritiated thymidine pulse labelling for marking $S$ phase cells in paraffin sections from animal and human tissues. Cell Tissue Kinet. 22:383-392.

18. Kerr, J. F. K., A. H. Wyllie, and A. H. Currie. 1972. Apoptosis, a basic biological phenomenon with a wider implication in tissue kinetics. Br. J. Cancer. 239:245.

19. Raff, M. C. 1992. Social controls on cell survival and cell death. Nature (Lond.). 356:397-400.

20. Gavrieli, Y., Y. Sherman, and S. A. Ben-Sasson. 1992. Identification of programmed cell death in situ via specific labeling of nuclear DNA fragmentation. J. Cell Biol. 119:493-501.

21. Shvil, Y., T. Naveh-Many, P. Barach, and J. Silver. 1990. Regulation of parathyroid cell gene expression in experimental uremia. J. Am. Soc. Nephrol. 1:99-104.

22. Okazaki, T., U. Chung, T. Nishishita, S. Ebisu, S. Usuda, S. Mishiro, S. Xanthoudakis, T. Igarashi, and E. Ogata. 1994. A redox factor protein, ref1, is involved in negative gene regulation by extracellular calcium. J. Biol. Chem. 269:27855-27862.

23. Peer, J. and N. Livni. 1994. PC-10 immunostaining of PCNA in posterior uveal melanoma. Ophthalmology 101:56-62.

24. Szabo, A., J. Merke, E. Beier, G. Mall, and E. Ritz. 1989. 1,25(OH)2 vitamin D3 inhibits parathyroid cell proliferation in experimental uremia. Kidney Int. 35:1049-1056.

25. Demay, M. B., M. S. Kiernan, H. F. DeLuca, and H. M. Kronenberg. 1992. Sequences in the human parathyroid hormone gene that bind the 1,25 dihydroxyvitamin D3 receptor and mediate transcriptional repression in response to 1,25-dihydroxyvitamin D3. Proc. Natl. Acad. Sci. USA. 89:8097-8101.

26. Naveh-Many, T., R. Kilav, E. Moallem, and J. Silver. 1994. Post-transcriptional regulation of the PTH gene by calcium and phosphate in vivo. J. Bone Miner. Res. 9:S338.(Abstr.)

27. Brown, E. M., G. Gamba, D. Ricardi, D. Lombardi, R. Butters, O. Kifor, M. Hediger, and S. C. Hebert. 1993. Cloning, expression, and characterization of a G-protein-coupled, bovine parathyroid $\mathrm{Ca}^{2+}$ receptor. J. Bone Miner. Res. 8:S147.(Abstr.)

28. Lu, K. P., and A. R. Means. 1993. Regulation of the cell cycle by calcium and calmodulin. Endocrine Rev. 14:40- 58. 
29. Nemeth, E. F., and A. Scarpa. 1987. Rapid mobilization of cellular $\mathrm{Ca}^{2+}$ in bovine parathyroid cells evoked by extracellular divalent cations. Evidence for a cell surface calcium receptor. J. Biol. Chem. 262:5188-5196.

30. Holmgren, L., M. S. O'Reilly, and J. Folkman. 1995. Dormancy of micrometastases: balanced proliferation and apoptosis in the presence of angogenesis suppression. Nature Med. 1:149-153.

31. Roth, S. I., and L. G. Raisz. 1964. Effect of calcium concentration on the ultrastructure of rat parathyroid in organ culture. Lab. Invest. 13:331-345.

32. Brandi, M. L., L. A. Fitzpatrick, H. G. Coon, and G. D. Aurbach. 1986 Bovine parathyroid cells: cultures maintained for more than 140 population doublings. Proc. Natl. Acad. Sci. USA. 83:1709-1713.

33. Kremer, R., I. Bolivar, D. Goltzman, and G. N. Hendy. 1989. Influence of calcium and 1,25-dihydroxycholecalciferol on proliferation and proto-oncogene expression in primary cultures of bovine parathyroid cells. Endocrinol. 125:935941.

34. Brown, A. J., M. Zhong, C. S. Ritter, E. M. Brown, and E. Slatopolsky 1994. Loss of calcium responsiveness in cultured parathyroid cells is associated with decreased expression of the calcium receptor. J. Am. Soc. Nephrol. 5:877.(Abstr.)

35. Stanbury, S. W. 1981. Vitamin D and hyperparathyroidism: the Lumleian Lecture 1981. J. R. Coll. Physicians. Lond. 15:205-9, 212-7.

36. Rivkees, S. A., G. El-Hajj-Fuleihan, E. M. Brown, and J. D. Crawford. 1992. Tertiary hyperparathyroidism during high phosphate therapy of familia hypophosphatemic rickets. J. Clin. Endocrinol. Metab. 75:1514-1518.

37. Nygren, P., R. Larsson, H. Johansson, S. Ljunghall, J. Rastad, and G. Akerstrom. 1988. 1,25( $(\mathrm{OH})_{2} \mathrm{D}_{3}$ inhibits hormone secretion and proliferation but not functional dedifferentiation of cultured bovine parathyroid cells. Calcif. Tissue. Int. 43:213-218.

38. Reitsma, P. H., P. G. Rothberg, S. M. Astrin, J. Trial, Z. Bar-Shavit, A Hall, S. L. Teitelbaum, and A. J. Kahn. 1983. Regulation of myc gene expression in HL-60 leukaemia cells by a vitamin D metabolite. Nature (Lond.). 306:492494.

39. Lopez-Hilker, S., A. S. Dusso, N. S. Rapp, K. J. Martin, and E. Slatopolsky. 1990. Phosphorus restriction reverses hyperparathyroidism in uremia independent of changes in calcium and calcitriol. Am. J. Physiol. 259:F432-F437.

40. Lucas, P. A., R. C. Brown, J. S. Woodhead, and G. A. Coles. 1986. 1,25-dihydroxycholecalciferol and parathyroid hormone in advanced chronic renal failure: effects of simultaneous protein and phosphorus restriction. Clin. Nephrol. 25:7-10.

41. Lafage, M. H., C. Combe, A. Fournier, and M. Aparicio. 1992. Ketodiet, physiological calcium intake and native vitamin D improve renal osteodystrophy. Kidney Int. 42:1217-1225.

42. Motokura, T., T. Bloom, H. G. Kim, H. Juppner, J. V. Ruderman, H. M. Kronenberg, and A. Arnold. 1991. A novel cyclin encoded by a bcll-linked candidate oncogene. Nature (Lond.). 350:512-515.
43. Motokura, T., and A. Arnold. 1993. PRAD1/cyclin D1 proto-oncogene: genomic organization, 5 ' DNA sequence, and sequence of a tumor-specific rearrangement breakpoint. Genes. Chromosom. Cancer 7:89-95.

44. Cryns, V. L., A. Thor, H-J. Xu, S-X. Hu, M. E. Wierman, A. L. Vickery, W. F. Benedict, and A. Arnold. 1994. Loss of the retinoblastoma tumor-suppressor gene in parathyroid carcinoma. N. Engl. J. Med. 330:757-761.

45. Arnold, A. 1994. Molecular Basis of Primary Hyperparathyroidism. In The Parathyroids. J. P. Bilezikian, M. A. Levine, and R. Marcus, editors. Raven Press, Ltd., New York. 407-421.

46. Law, W. M. J., and H. Heath. 1985. Familial benign hypercalcemia (hypocalciuric hypercalcemia). Clinical and pathogenetic studies in 21 families. Ann Intern. Med. 102:511-519.

47. Khosla, S., P. R. Ebeling, A. F. Firek, M. M. Burritt, P. C. Kao, and H. Heath. 1993. Calcium infusion suggests a "set-point" abnormality of parathyroid gland function in familial benign hypercalcemia and more complex disturbances in primary hyperparathyroidism. J. Clin. Endocrinol. Metab. 76:715-720.

48. Pollack, M. R., E. M. Brown, Y-H. W. Chou, S. C. Hebert, S. J. Marx B. Steinman, T. Levi, C. E. Seidman, and J. G. Seidman. 1993. Mutations in the human $\mathrm{Ca}^{2+}$-sensing receptor gene cause familial hypocalciuric hypercalcemia and neonatal severe hyperparathyroidism. Cell. 75:1297-1303.

49. Friedman, E., K. Sakaguchi, A. E. Bale, A. Falchetti, E. Streeten, M. B. Zimering, L. S. Weinstein, W. O. McBride, Y. Nakamura, M-L Brandi, J. F Norton, G. D. Aurbach, A. M. Spiegel, and S. J. Marx. 1989. Clonality of parathyroid tumors in familial multiple endocrine neoplasia type 1. New Engl. J. Med. 321:213-218.

50. Thakker, R. V., P. Bouloux, C. Wooding, K. Chotai, P. M. Broad, N. K. Spurr, G. M. Besser, and J. L. H. O'Riordan. 1989. Association of parathyroid tumors in multiple endocrine neoplasia type 1 with loss of alleles on chromosome 11. N. Engl. J. Med. 321:218-224.

51. Ceccherini, I., C. Romei, V. Barone, F. Pacini, E. Martino, A. Loviselli, A. Pinchera, and G. Romeo. 1994. Identification of the Cys634 $\rightarrow$ Tyr mutation of the RET proto-oncogene in a pedigree with multiple endocrine neoplasia type $2 \mathrm{~A}$ and localized cutaneous lichen amyloidosis. J. Endocrinol. Invest. 17:201204

52. Hofstra, R. M. W., R. M. Landsvater, I. Ceccherini, R. P. Stulp, T Stelwagen, Y. Luo, B. Pasini, J. W. M. Hoppener, H. K. P. van Amstel, G. Romeo, C. J. M. Lips, and C. H. C. M. Buys. 1994. A mutation in the RET protooncogene associated with multiple endocrine neoplasia type $2 \mathrm{~B}$ and sporadic thyroid carcinoma. Nature (Lond.). 367:375- 376.

53. Tsai, M. S., G. A. Ledger, S. Khosla, H. Gharib, and S. N. Thibodeau. 1994. Identification of multiple endocrine neoplasia, type 2 gene carriers using linkage analysis and analysis of the RET proto-oncogene. J. Clin. Endocrinol. Metab. 78:1261-1264.

54. Arnold, A., M. F. Brown, P. Urena, R. D. Gaz, E. Sarfati, and T. B. Drueke. 1995. Monoclonality of parathyroid tumors in chronic renal failure and in primary parathyroid hyperplasia. J. Clin. Invest. 95:1047-2053. 